\title{
Overview of neuromuscular adaptations of skeletal muscle to KAATSU Training
}

\author{
M. Karabulut, T. Abe, Y. Sato, M. Bemben
}

Int. J. KAATSU Training Res. 2007; 3: 1-9

Correspondence to:

M. Karabulut, Department of Health and Exercise Science, University of Oklahoma, 1401 Asp Avenue, Norman, OK, USA

E-mail: muratk@ou.edu

See end of article for author's affiliations

\begin{abstract}
Skeletal muscle adapts to a progressive overload, but the response can vary between different modes and intensities of exercise. Generally, a minimal threshold intensity of $65 \%$ of the one repetition maximum (1-RM) is needed to elicit muscle hypertrophy; however, recent studies have challenged this hypothesis and have provided evidence that low-intensity training (LIT) combined with vascular restriction (KAATSU) may also elicit increases in muscle size and strength. The physiological aspects of applying vascular restriction during exercise are not fully understood and may be explained by several factors. Examining the results of previous studies may help elucidate the factors responsible for the adaptations associated with vascular restriction in humans. Therefore, the objectives of this review are to summarize current knowledge regarding the physiological adaptations of skeletal muscle after low-intensity exercise combined with vascular restriction, the different training protocols used to elicit adaptations, and suggested areas for future research.
\end{abstract}

Key words: blood restriction, skeletal muscle, hypertrophy, KAATSU.

\section{INTRODUCTION}

Skeletal muscle can adapt positively when the appropriate training principles are followed. Central to the concept of physiological adaptation are the training principles dealing with overload, progression, and adaptation. It is well established that in order for physiological adaptation to occur, the exercise intensity must be sufficient to elicit the desired training response, i.e., muscle hypertrophy, muscle power, muscular endurance, etc. Intensity of the exercise and training volume can be manipulated in several ways, for example, increasing the load being lifted or by increasing the frequency of training (times per week) or the duration of a single bout of exercise. Often times, positive adaptations can take several weeks (as seen with skeletal muscle changes) or even several months (as seen with bone changes) before improvements can be noted.

The recent development of exercise training at greatly reduced intensities when combined with blood flow restriction (KAATSU) has challenged many of the widely accepted principles of exercise training (Sato, 2005). A number of studies have demonstrated that low-intensity resistance exercise (i.e., 20\% 1-RM) combined with vascular restriction (KAATSU) can elicit increases in muscle size [Abe et al., 2006; Beekley et al., 2005; Takarada et al., 2002; Takarada et al., 2000a] and strength [Shinohara et al., 1998; Takarada et al., 2002] to a similar or even greater extent then traditional resistance training utilizing intensities greater than the recommended 65\% 1-RM threshold [Goto et al., 2005; Goto et al.,
2004; McCall et al., 1999]. Although the precise mechanisms underlying these adaptations remain unclear, reducing the relative intensity of resistance training to $20 \%$ l-RM and including vascular restriction would have obvious advantages for individuals who may exhibit limited strength or health-related risks with higher resistance training loads, such as older adults and diseased or injured patients. In addition to the relative low intensity (20\% 1-RM) utilized with KAATSU (even though the absolute intensity may be as high or higher than traditional training loads), other important aspects such as shorter training periods (duration) and lower volumes of work (load x sets $\mathrm{x}$ reps) are needed to induce muscle hypertrophy and improve strength when compared to traditional resistance training principles. Generally, training volumes utilizing moderate to higher number of repetitions per set $(6$ to 12 ) at $67-85 \%$ 1-RM have been associated with muscle hypertrophy [Baechle and Earle, 2000]; however, KAATSU training requires much lower exercise volumes for similar or even a greater hypertrophic response of skeletal muscle. Since increases in skeletal muscle size in response to KAATSU training is relatively fast (even after one week of KAATSU training) and can be achieved with low training volumes, this may be useful from a clinical standpoint for decreasing rehabilitation time following injury.

A review of the available evidence on training in combination with vascular restriction may help elucidate the physiological mechanisms responsible 
for skeletal muscle adaptation. The following paper is a brief summary of the recent history of skeletal muscle adaptation to lower intensity exercise when accompanied by vascular occlusion, which has its' modest beginning in the late 1990's [Shinohara et al., 1998; Yoshida and Watari, 1997] but has recently become an area of increased interest for many researchers. Detailed information about each of the studies examined in this review such as the exercises performed, if control groups were included, subject information (gender, training frequency, etc.), and the pressures used to induce blood flow restriction are provided in Tables 1 and 2. This paper will present both KAATSU training responses and acute findings related to vascular restriction on skeletal muscle physiology in humans.

\section{TRAINING RESPONSES \\ 1. Hypertrophy \\ Duration and intensity of training}

Muscular hypertrophy is an adaptation to increasing work loads that exceeds the capacity of the muscle fiber, resulting in an increase in muscle mass and cross-sectional area [Russell et al., 2000]. Traditional resistance training programs use high intensity ( $\geq 65 \%$ l-RM) exercises to elicit muscle hypertrophy. One study reported that the crosssectional area (CSA) of the biceps brachii muscle increased by $\sim 11 \%$ following a training protocol consisting of three sets of 10 repetition maximum ( $75 \%$ 1-RM) for 8 exercises during a 12 week period (33 sessions) [McCall et al., 1999]. Others have investigated the effects of combinations of different intensity resistance exercises on muscular adaptations [Goto et al., 2004]. Subjects performed nine sets of exercises at varied intensities (from 40 to $80 \%$ l-RM), during a designed hypertrophy phase (6-week). Following this 6-week hypertrophy phase, subjects were then assigned to either a hypertrophy / combination (HC) or a hypertrophy / strength (HS) group and performed leg press and knee extension exercises for an additional four weeks (strength phase). The HS group performed 5 sets of leg exercises at 3-5 RM ( 90\% 1-RM), whereas the HC group performed the same protocol as the HS group but included an additional set of low-intensity and high-repetition exercise at 25-35 RM ( 50\% 1-RM) during the strength phase. Both groups experienced similar changes in muscle CSA $(\sim 4 \%)$ after completion of the hypertrophy phase; however, only the $\mathrm{HC}$ training program resulted in a further increase in CSA $(\sim 2 \%)$ compared to HS training protocol. These studies suggest that the intensity and volume of traditional training programs are important factors and should always be considered in order to induce hypertrophic responses.

On the other hand, recent KAATSU studies (summarized in Table 1) indicate that the intensity and volume of training do not have to be high when compared to traditional resistance training programs in order to elicit skeletal muscle hypertrophy. Researchers have reported statistically significant increases in muscle size in mid-thigh muscles of $8.5 \%$ in a KAATSU group compared to a group performing the same protocol without blood flow restriction (noKAATSU) [Abe et al., 2005b]. KAATSU and noKAATSU groups also experienced changes in muscle volumes for the quadriceps $(7.7 \%$ and $1.4 \%$, respectively) biceps femoris $(10.1 \%$ and $1.9 \%$, respectively) and gluteus maximus $(9.1 \%$ and $0.6 \%$, respectively) after two-weeks of twice daily low intensity (20\% $1-\mathrm{RM})$ resistance training; however, only the changes with the KAATSU protocol were statistically significant following training and changes in muscle size with KAATSU were similar to those utilizing traditional highintensity resistance training programs for 3 months [Goto et al., 2005; McCall et al., 1999]. Additionally, one week of twice-daily KAATSU training consisting of knee extension exercises at $20 \%$ of 1-RM resulted in a 3\% increase in the quadriceps muscle CSA [Abe et al., 2005a], whereas completion of an 8-week training program that included five sets of knee extension exercises at an intensity of $20 \%$ l-RM with KAATSU resulted in a $10.3 \%$ increase in knee extension CSA, but no significant changes in muscle CSA were determined when exercising at the same intensity without blood flow restriction [Takarada et al., 2004]. Finally, Yasuda et al (2005) observed a $7.8 \%$ and a $1.8 \%$ increase in quadriceps muscle CSA in KAATSU and no-KAATSU groups, respectively, after a 2 -week training (at 20\% 1-RM) program. Type I and Type II muscle fiber CSA increased $5.9 \%$ and $27.6 \%$ following KAATSU training, whereas changes in Type I and Type II fiber CSA were $-2.1 \%$ and $0.5 \%$ after no-KAATSU training, respectively. The findings suggest that skeletal muscle hypertrophic responses may not only be due to changes in water balance created by blood flow restriction, but due to increased protein synthesis.

It appears as though when KAATSU is used in combination with resistance training (20\% 1-RM) that the adaptation period is greatly reduced (one to two weeks) compared to the time required to demonstrate significant changes from traditional resistance training programs $(80 \% 1-R M$ and 8 to 16 weeks) and that the relative intensity of the training program is also lower (20\% 1-RM versus $80 \% 1$ $\mathrm{RM})$.

\section{Modes of training}

Generally, the application of external pressures to produce vascular restriction, have been used in combination with resistance training, but the 
Table 1.

Training Studies on the Effects of Vascular Restriction on Skeletal Muscle Physiology

\begin{tabular}{|c|c|c|c|c|c|c|c|c|c|c|c|}
\hline Author & Group & $\begin{array}{l}\text { Duration } \\
\text { of Study } \\
\text { (Week) }\end{array}$ & $\mathbf{N}$ & Gender & $\begin{array}{l}\text { Freq } \\
(\mathrm{d} / \mathrm{wk})\end{array}$ & Set $x$ Rep & Intensity & $\begin{array}{l}\text { Change in } \\
\text { CSA } \\
\text { Increase }(\uparrow) \\
\text { Decrease }(\downarrow)\end{array}$ & $\begin{array}{l}\text { Change in } \\
\text { Strength } \\
\text { Increase }(\uparrow) \\
\text { Decrease }(\downarrow)\end{array}$ & $\begin{array}{l}\text { Change in EMG, } \\
\text { MMG, motor unit } \\
\text { activation, PAP } \\
\text { Increase }(\uparrow) \\
\text { Decrease }(\downarrow)\end{array}$ & Comments \\
\hline $\begin{array}{l}\text { Abe et al. } \\
(2005 a)\end{array}$ & $\mathrm{E}$ & $1 \mathrm{wk}$ & 1 & $M$ & $7 \mathrm{~d}$ & $\begin{array}{l}30 \text { reps }+3 \\
x 15 \text { reps of } \\
\text { knee } \\
\text { extension }\end{array}$ & $20 \%$ 1-RM & $\begin{array}{l}3.5 \%(\uparrow) \text { in } \\
\text { quadriceps }\end{array}$ & $\begin{array}{l}17 \%(\uparrow) \text { in } \\
\mathrm{MVC} \\
14 \%(\uparrow) \text { in } \\
1-\mathrm{RM}\end{array}$ & NA & $\begin{array}{l}\text { The cuff pressure: } \\
\text { day } 1=160 \text { day } 4= \\
220 \mathrm{mmHg} \text {. } \\
30 \mathrm{sec} \text { rest } \\
\text { between sets. }\end{array}$ \\
\hline $\begin{array}{l}\text { Abe et al. } \\
(2005 b)\end{array}$ & $\mathrm{E}$ & $2 \mathrm{wk}$ & 9 & M & $6 \mathrm{x} / \mathrm{wk}$ & $\begin{array}{l}3 \times 15 \text { reps } \\
\text { of squad }+ \\
\text { leg press } \\
3 \times 15 \text { reps } \\
\text { of squad }+ \\
\text { leg press }\end{array}$ & $20 \% 1-\mathrm{RM}$ & $\begin{array}{l}8.5 \%(\uparrow) \text { in } \\
\text { mid-thigh } \\
1.8 \%(\uparrow) \text { in } \\
\text { mid-thigh }\end{array}$ & \begin{tabular}{|l|}
$16.8 \%(\uparrow)$ in \\
squad \\
$22.6 \%(\uparrow)$ in leg \\
curl \\
\\
$8.9 \%(\uparrow)$ in \\
squad \\
$1.3 \%(\uparrow)$ in leg \\
curl
\end{tabular} & NA & $\begin{array}{l}\text { The cuff pressure }= \\
\text { Day } 1=160 \\
\text { Day } 9=240 \mathrm{mmHg} \\
30 \mathrm{sec} \text { rest } \\
\text { between sets. }\end{array}$ \\
\hline $\begin{array}{l}\text { Abe et al. } \\
(2006)\end{array}$ & $\mathrm{C}$ & $3 \mathrm{wk}$ & 9 & M & $\begin{array}{l}2 \mathrm{x} / \mathrm{d} \\
6 \mathrm{x} / \mathrm{wk}\end{array}$ & $\begin{array}{l}5 \times 2 \mathrm{~min} \\
\text { walking }\end{array}$ & $50 \mathrm{~m} / \mathrm{min}$ & $\begin{array}{l}5.7 \%(\uparrow) \text { in } \\
\text { Quads } \\
7.6 \%(\uparrow) \text { in } \\
\text { hamstrings } \\
\text { No sig. } \\
\text { change }\end{array}$ & \begin{tabular}{|l|}
$7.4 \%(\uparrow)$ in leg \\
press $(1-\mathrm{RM})$ \\
$8.3 \%(\uparrow)$ in leg \\
curl $(1-\mathrm{RM})$ \\
Hamstrings \\
$10.4 \%(\uparrow)$ in \\
knee ex. (MVC) \\
$9.4 \%(\uparrow)$ in knee \\
flex. (MVC) \\
No sig. change \\
\end{tabular} & NA & $\begin{array}{l}\text { The cuff pressure: } \\
200 \mathrm{mmHg} \\
\text { Walking study }\end{array}$ \\
\hline $\begin{array}{l}\text { Burgomaster } \\
\text { et al. (2003) }\end{array}$ & $\mathrm{E}$ & $8 \mathrm{wk}$ & 8 & M & $2 \mathrm{x} / \mathrm{wk}$ & $\begin{array}{l}2 \mathrm{x} / 10+ \\
1 \mathrm{x} / \text { failure } \\
\left.\text { ( } 1^{\text {st }} 2 \mathrm{wk}\right) \\
\text { \# of sets } \\
\text { increased } \\
\text { by } 1-\text { set/wk } \\
5 \mathrm{x} / 10+1 \mathrm{x} \\
/ \text { failure } \\
\text { (from wk } 5 \\
\text { to } 8 \text { ) } \\
\text { \# of } \\
\text { repetitions } \\
\text { were } \\
\text { matched } \\
\text { with the } \\
\text { occluded } \\
\text { arm }\end{array}$ & $50 \% 1-\mathrm{RM}$ & NA & $\begin{array}{l}\text { 9.6\% }(\uparrow) \text { in } \\
\text { isokinetic } \\
\text { strength } \\
23 \%(\uparrow) \text { in } \\
\text { isotonic } \\
\text { strength }\end{array}$ & NA & $\begin{array}{l}\text { The cuff } \\
\text { pressure: } \\
100 \mathrm{mmHg} \\
\text { One min rest } \\
\text { between sets } \\
\text { and } 5 \text { min rest } \\
\text { between } \\
\text { blocks (3 } \\
\text { sets= a block) } \\
\text { The } \\
\text { contralateral } \\
\text { arms were } \\
\text { trained } \\
\text { without } \\
\text { occlusion }\end{array}$ \\
\hline $\begin{array}{l}\text { Ishii et al. } \\
\text { (2005) }\end{array}$ & $\mathrm{E}$ & $8 \mathrm{wk}$ & 11 & $\mathrm{~F}$ & $3 \mathrm{x} / \mathrm{wk}$ & $\begin{array}{l}6 \text { exercises } \\
\text { (knee-up, } \\
\text { bent-knee } \\
\text { push up, } \\
\text { leg raise, } \\
\text { seated knee } \\
\text { flexion, } \\
\text { squad, and } \\
\text { forward } \\
\text { lunge). } \\
\text { Number of } \\
\text { repetitions } \\
\text { varied. }\end{array}$ & NA & $\begin{array}{l}3 \% \text { increase } \\
\text { No sig. change }\end{array}$ & NA & NA & $\begin{array}{l}\text { The cuff } \\
\text { pressure: } \\
50-80 \text { for } \\
\text { upper limbs } \\
80-120 \\
\text { mmHg for } \\
\text { lower limbs. } \\
\text { (KAATSU } \\
\text { sportswear) } \\
\text { Circuit } \\
\text { training } \\
\text { (No external } \\
\text { loading) }\end{array}$ \\
\hline $\begin{array}{l}\text { Moore et } \\
\text { al. (2004) }\end{array}$ & $\mathrm{E}$ & $8 \mathrm{wk}$ & 8 & M & $2 \mathrm{x} / \mathrm{wk}$ & $\begin{array}{l}2 \mathrm{x} / 10+ \\
1 \mathrm{x} / \mathrm{failure} \\
\left(1^{\text {st }} 2 \mathrm{wk}\right) \\
\text { \# of sets } \\
\text { increased } \\
\text { by } 1 \text {-set/wk } \\
5 \mathrm{x} / 10+1 \mathrm{x} \\
/ \text { failure } \\
\text { (from wk } 5 \\
\text { to } 8 \text { ) } \\
\text { \# of } \\
\text { repetitions } \\
\text { were } \\
\text { matched } \\
\text { with the } \\
\text { occluded } \\
\text { arm }\end{array}$ & $50 \% 1-\mathrm{RM}$ & NA & \begin{tabular}{|l|}
$22 \%(\uparrow)$ in \\
dynamic \\
strength \\
$8 \%(\uparrow)$ in MVC \\
\\
\\
\\
$23 \%(\uparrow)$ in \\
dynamic \\
strength \\
No sig. change \\
in MVC
\end{tabular} & $\begin{array}{l}51 \%(\uparrow) \text { in PAP } \\
\text { No sig. change in } \\
\text { EMG activity \& } \\
\text { motor unit activation. } \\
\\
\text { Greater relative }(\uparrow) \text { in } \\
\text { EMG activity from } \\
1^{\text {st }} \text { rep of set-1 to } 1^{\text {st }} \\
\text { rep of set-3 } \\
21 \%(\downarrow) \text { in resting } \\
\text { twitch peak torque } \\
\text { No sig. change in } \\
\text { PAP, EMG activity, } \\
\& \text { motor unit } \\
\text { activation }\end{array}$ & $\begin{array}{l}\text { The cuff } \\
\text { pressure: } \\
100 \mathrm{mmHg} \\
\text { One min rest } \\
\text { between sets and } \\
5 \text { min rest } \\
\text { between blocks } \\
\text { ( } 3 \text { sets= a block) } \\
\text { The } \\
\text { contralateral } \\
\text { arms were } \\
\text { trained without } \\
\text { occlusion }\end{array}$ \\
\hline $\begin{array}{l}\text { Sata S. } \\
\text { (2005) }\end{array}$ & $\mathrm{E}$ & $3 \mathrm{wk}$ & 1 & M & $5-6 \mathrm{x} / \mathrm{wk}$ & $\begin{array}{l}3 \times 15 \\
(8 \\
\text { exercises })\end{array}$ & $30 \%$ 1-RM & $\begin{array}{l}7 \mathrm{~mm}(\uparrow) \text { in } \\
\text { right thigh } \\
\text { and } \\
2 \mathrm{~mm}(\uparrow) \text { in } \\
\text { left thigh } \\
\text { circum. }\end{array}$ & NA & NA & $\begin{array}{l}\text { Subject was one } \\
\text { patella tendinitis } \\
\text { patient }\end{array}$ \\
\hline
\end{tabular}


Table 1. (continued)

\begin{tabular}{|c|c|c|c|c|c|c|c|c|c|c|c|}
\hline Author & Group & $\begin{array}{l}\text { Duration } \\
\text { of Study } \\
\text { (Week) }\end{array}$ & $\mathbf{N}$ & Gender & $\begin{array}{l}\text { Freq } \\
(d / w k)\end{array}$ & Set $x$ Rep & Intensity & $\begin{array}{l}\text { Change in } \\
\text { CSA } \\
\text { Increase }(\uparrow) \\
\text { Decrease }(\downarrow)\end{array}$ & $\begin{array}{l}\text { Change in } \\
\text { Strength } \\
\text { Increase }(\uparrow) \\
\text { Decrease }(\downarrow)\end{array}$ & $\begin{array}{l}\text { Change in EMG, } \\
\text { MMG, motor unit } \\
\text { activation, PAP } \\
\text { Increase }(\uparrow) \\
\text { Decrease }(\downarrow)\end{array}$ & Comments \\
\hline $\begin{array}{l}\text { Shinohara } \\
\text { et al. } \\
\text { (1998) }\end{array}$ & $\mathrm{E}$ & $4 \mathrm{wk}$ & 5 & $\mathrm{M}$ & $3 \mathrm{x} / \mathrm{wk}$ & $\begin{array}{l}\text { 36x } \\
\text { isometric } \\
\text { knee } \\
\text { extension } \\
\text { (2s on } 3 \mathrm{~s} \\
\text { off) }\end{array}$ & $40 \% \mathrm{MVC}$ & NA & $\begin{array}{l}9 \% \& 26 \%(\uparrow) \\
\text { in ischemic-leg } \\
\text { after 2-wk \& 4- } \\
\text { wk, respectively } \\
\text { No sig. change } \\
\text { in non-ischemic- } \\
\text { leg }\end{array}$ & NA & $\begin{array}{l}\text { The cuff } \\
\text { pressure: } \\
>250 \mathrm{mmHg} \\
\text { Same subjects } \\
\text { trained with one } \\
\text { leg ischemic and } \\
\text { the other non- } \\
\text { ischemic }\end{array}$ \\
\hline $\begin{array}{l}\text { Takarada } \\
\text { et al. } \\
\text { (2000a) }\end{array}$ & $\mathrm{E}$ & $2 \mathrm{wk}$ & 8 & $\begin{array}{l}4 \mathrm{M} \\
4 \mathrm{~F}\end{array}$ & $\begin{array}{l}2 \mathrm{x} / \mathrm{d} \\
12 \\
\text { days } \\
\text { (betwe } \\
\text { en the } \\
3^{\text {rd }} \\
\text { and } \\
14^{\text {th }} \\
\text { days } \\
\text { after } \\
\text { operati } \\
\text { on) }\end{array}$ & $\begin{array}{l}5 \times 5 \text { min } \\
\text { blood flow } \\
\text { restriction }\end{array}$ & $\begin{array}{l}\text { A cuff was } \\
\text { inflated } \\
\text { No exercise } \\
\begin{array}{l}\text { A cuff was } \\
\text { on, but not } \\
\text { inflated }\end{array}\end{array}$ & $\begin{array}{l}9.4 \%(\downarrow) \text { in } \\
\text { knee } \\
\text { extensors } \\
9.2 \%(\downarrow) \text { in } \\
\text { knee flexors } \\
\\
\\
20.7 \%(\downarrow) \text { in } \\
\text { knee } \\
\text { extensors } \\
11.3 \%(\downarrow) \text { in } \\
\text { knee flexors }\end{array}$ & NA & NA & $\begin{array}{l}\text { Mean cuff } \\
\text { pressure: } \\
238 \mathrm{mmHg} \\
3 \text { min rest } \\
\text { between } \\
\text { occlusions } \\
\text { Patients with an } \\
\text { operation for the } \\
\text { reconstruction } \\
\text { of the anterior } \\
\text { cruciate } \\
\text { ligament }\end{array}$ \\
\hline $\begin{array}{l}\text { Takarada } \\
\text { et al. } \\
\text { (2002) }\end{array}$ & E & $8 \mathrm{wk}$ & 6 & M & $2 \mathrm{x} / \mathrm{wk}$ & $\begin{array}{l}\text { Subjects } \\
\text { repeated } \\
\text { the lifting } \\
\text { (knee } \\
\text { extension) } \\
\text { until failure } \\
4 \mathrm{x} \\
\text { \# of } \\
\text { repetitions } \\
\text { were } \\
\text { matched } \\
\text { with } \\
\text { vascular } \\
\text { occlusion } \\
\text { group } \\
\text { untrained }\end{array}$ & $50 \% 1-\mathrm{RM}$ & $\begin{array}{l}12.3 \%(\uparrow) \text { in } \\
\text { knee } \\
\text { extensors }\end{array}$ & $\begin{array}{l}3.2 \%(\uparrow) \text { in } \\
\text { isokinetic torque } \\
\text { (averaged over } \\
\text { all velocities) }\end{array}$ & NA & $\begin{array}{l}\text { Mean cuff } \\
\text { pressure: } \\
200 \mathrm{mmHg} \\
30 \text { sec rest } \\
\text { between sets. }\end{array}$ \\
\hline $\begin{array}{l}\text { Takarada } \\
\text { et al. } \\
\text { (2004) }\end{array}$ & $\mathrm{E}$ & $8 \mathrm{wk}$ & 6 & M & $2 \mathrm{x} / \mathrm{wk}$ & $\begin{array}{l}\text { 5x subjects } \\
\text { repeated } \\
\text { the lifting } \\
\text { until failure } \\
\\
\text { 5x subjects } \\
\text { repeated } \\
\text { the lifting } \\
\text { until failure } \\
10 \text { min } \\
\text { vascular } \\
\text { occlusion }\end{array}$ & untrained & $\begin{array}{l}10.3 \%(\uparrow) \text { in } \\
\text { knee } \\
\text { extensors } \\
\text { No sig. } \\
\text { change }\end{array}$ & $\begin{array}{l}9.2 \%(\uparrow) \text { in } \\
\text { isokinetic } \\
\text { strength } \\
\\
3.1 \%(\uparrow) \text { in } \\
\text { isokinetic } \\
\text { strength } \\
2.8 \%(\uparrow) \text { in } \\
\text { isokinetic } \\
\text { strength }\end{array}$ & NA & $\begin{array}{l}\begin{array}{l}\text { Mean cuff } \\
\text { pressure: } 218 \\
\text { mmHg }\end{array} \\
\text { 1-minute rest } \\
\text { between sets. }\end{array}$ \\
\hline $\begin{array}{l}\text { Takarada } \\
\text { et al. } \\
(2000 \mathrm{~b})\end{array}$ & $\mathrm{C}$ & $16 \mathrm{wk}$ & 11 & W & $2 \mathrm{x} / \mathrm{wk}$ & $\begin{array}{l}\text { Subjects } \\
\text { performed } \\
5 \text { sets of } \\
\text { single-arm } \\
\text { dumbbell } \\
\text { curl, each } \\
\text { set until } \\
\text { failure } \\
\\
\# \text { of } \\
\text { repetitions } \\
\text { were } \\
\text { matched } \\
\text { with } \\
\text { vascular } \\
\text { occlusion } \\
\text { group } \\
5 x \text { of } \\
\text { single-arm } \\
\text { dumbbell } \\
\text { curl }\end{array}$ & $\begin{array}{l}\sim 30-50 \% 1 \text { - } \\
\mathrm{RM} \\
\sim 50-80 \% 1 \text { - } \\
\mathrm{RM} \\
\sim 50 \% 1- \\
\mathrm{RM} \\
\text { untrained }\end{array}$ & $\begin{array}{l}20.3 \%(\uparrow) \text { in } \\
\text { biceps brachii } \\
17.8 \%(\uparrow) \text { in } \\
\text { brachialis } \\
18.4 \%(\uparrow) \text { in } \\
\text { biceps brachii } \\
11.8 \%(\uparrow) \text { in } \\
\text { brachialis } \\
6.9 \%(\uparrow) \text { in } \\
\text { biceps brachii } \\
3.8 \%(\uparrow) \text { in } \\
\text { brachialis }\end{array}$ & $\begin{array}{l}18.4 \%(\uparrow) \text { in } \\
\text { isokinetic } \\
\text { strength } \\
22.6 \%(\uparrow) \text { in } \\
\text { isokinetic } \\
\text { strength } \\
1.04 \%(\uparrow) \text { in } \\
\text { isokinetic } \\
\text { strength }\end{array}$ & $\begin{array}{l}\text { Sig. }(\uparrow) \text { in iEMG } \\
\text { compared to exercise } \\
\text { of same intensity } \\
\text { without restriction } \\
\text { No sig. change }\end{array}$ & $\begin{array}{l}\begin{array}{l}\text { Mean cuff } \\
\text { pressure: } 110 \\
\text { mmHg }\end{array} \\
\text { 1-minute rest } \\
\text { between sets. } \\
\text { Repeated the } \\
\text { lifting until } \\
\text { failure. } \\
\text { In the subjects } \\
\text { of occlusion } \\
\text { group, the } \\
\text { contralateral } \\
\text { arms were } \\
\text { trained with a } \\
\text { high intensity } \\
\text { exercise (80\% 1- } \\
\text { RM). }\end{array}$ \\
\hline $\begin{array}{l}\text { Yasuda et } \\
\text { al. (2005) }\end{array}$ & $\mathrm{E}$ & $2 \mathrm{wk}$ & 2 & $\mathrm{M}$ & $\begin{array}{l}2 \mathrm{x} / \mathrm{d} \\
6 \mathrm{x} / \mathrm{wk} \\
\\
2 \mathrm{x} / \mathrm{d} \\
6 \mathrm{x} / \mathrm{wk}\end{array}$ & 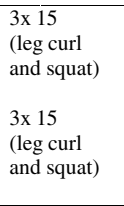 & $20 \% 1-\mathrm{RM}$ & $\begin{array}{l}7.8 \%(\uparrow) \text { in } \\
\text { quadriceps } \\
1.8 \%(\uparrow) \text { in } \\
\text { quadriceps }\end{array}$ & $\begin{array}{l}14 \%(\uparrow) \text { in } 1- \\
\mathrm{RM} \text { (squat) } \\
9.1 \%(\uparrow) \text { in } 1- \\
\mathrm{RM} \text { (squat) }\end{array}$ & NA & $\begin{array}{l}\text { The cuff } \\
\text { pressure }= \\
\text { Day } 1=160 \\
\text { Day } 9=240 \\
\text { mmHg } \\
30 \text { sec rest } \\
\text { between sets and } \\
\text { exercises. }\end{array}$ \\
\hline
\end{tabular}

Table was organized according to alphabetical order of nam es. N= Number of subjects; Freq= Frequency; Rep= Repetitions; E = Exercise group; C= Control group; $\mathrm{M}=$ Male; $\mathrm{F}=$ Female; NA= Not applicable. 
KAATSU technique has also been used with different modes of exercise to investigate skeletal muscle adaptation and response. Three weeks of twice-daily walk training combined with vascular restriction $(\mathrm{LIWT}+\mathrm{R})$ compared to walking alone (LIWT) resulted in an increase in quadriceps muscle CSA of $5.7 \%$ and $1.5 \%$, respectively (Abe et al., 2006), $7.5 \%$ and $-0.6 \%$, respectively [Beekley et al., 2005], and hamstring muscle CSA of $7.6 \%$ and $-1.7 \%$, respectively [Abe et al., 2006].

Using a different approach, subjects wearing "KAATSU Sportswear" (PHENIX Co. Ltd., Tokyo Japan) performed a circuit-training protocol only using body weight as the external load. The protocol consisted of six exercises (Table 1) with blood flow restriction to both upper and lower limbs for 8 weeks. The proximal ends of upper and lower limbs were compressed by elastic belts to restrict blood flow. The blood flow restriction pressure was determined by the stretched distance of the elastic belts and the circumference of the limbs. Thigh muscle CSA increased by $\sim 3 \%$ in KAATSU group but no change was observed after circuit training without blood flow restriction, although there was no statistical difference between the two groups (Ishii et al., 2005). These studies indicate that the combination of KAATSU technique with different modes of training programs may also be used to elicit hypertrophy but further research is needed to support these claims.

\section{Age related adaptation and training status}

Decreases in muscular strength with aging are attributed to declines in muscle fiber area [Grimby et al., 1982] and fiber number [Lexell et al., 1983]. Maintaining or improving muscular strength is very important for middle-aged and elderly populations so that quality of life can be maintained or improved. It is known that high intensity exercise is needed to induce muscle hypertrophy [Baechle and Earle, 2000], however, elderly people (70-79 years of age) may be prone to orthopedic injury or be unable to perform traditional high intensity strength testing and training [Pollock et al., 1991].

Middle-aged female subjects (47-67 yr) increased their biceps brachii and brachialis muscle size by $20.3 \%$ and $17.8 \%$, respectively, following a training protocol of five sets of single dumbbell curls at 30$50 \% 1-\mathrm{RM}$ with blood flow restriction for a 16-week training period [Takarada et al., 2000b]. However, the same training program without blood flow restriction resulted in an increase in CSA of the biceps brachii of only $6.9 \%$ and in the brachialis of $3.8 \%$. This finding suggests that KAATSU may be more effective and safer for improving muscle size in older individuals.

The positive effects of KAATSU on muscle size and strength have been reported not only in sedentary and active individuals but also in athletes and patients. The CSA of the knee extensors in athletes increased by $12.3 \%$ after an 8 -week period of KAATSU resistance training at $50 \%$ of $1-\mathrm{RM}$ indicating that low-intensity exercise with vascular restriction can increase muscle size and strength regardless of training status [Takarada et al., 2002].

\section{Rehabilitation}

It was reported that low intensity KAATSU resistance training has also been used as part of the rehabilitation process in Japan [Sata, 2005]. A patient with patellar tendinitis incorporated KAATSU training on the right injured limb along with exercises for both lower extremities at 30\% l-RM for 3 weeks. It was reported that the patient was able to begin jogging one week after beginning the KAATSU training and that thigh circumference increased by 7 $\mathrm{mm}$ for the injured right leg and $2 \mathrm{~mm}$ for the uninjured left leg after three weeks of KAATSU training. It should be noted that the patient received both anti-inflammatory drugs and a steroid injection; therefore the training results are somewhat confounded by the administration of the drugs. However, the quick recovery of this patient suggests that this training method may be safe and decrease recovery times in these types of patients. In addition, the application of vascular restriction without any exercise for a 2 -week period resulted in disuseinduced decreases in muscle CSA of the knee extensors and flexors of -9.4 and $-9.2 \%$, respectively but were significantly less than those in a control group without KAATSU application (-20.7 and $11.3 \%$, respectively) [Takarada et al., 2000a]. Based on these findings, it can be suggested that blood flow restriction alone may reduce atrophy associated with inactivity or when accompanied with low-intensity exercise may increase muscle size in a variety of patient populations.

\section{Strength and Neural Changes a. Strength Duration and intensity of training}

Generally, strength adaptations have been assessed by measuring isometric [maximal voluntary contraction (MVC)], isokinetic, or dynamic [one repetition maximum (1-RM)] muscle strength, which may be due to neural adaptations, muscle hypertrophy, or both. Measuring changes in muscle CSA or the total amount of muscle mass can explain strength changes due to hypertrophy, whereas measuring motor unit activation (MUA), post activation potentiation (PAP), recording electromyography (EMG) and mechanomyography (MMG) activities provides additional information regarding any neural changes.

Traditional resistance training prgrams often report significant increases in both muscle hypertrophy and 
strength of 5 to $39 \%$ depending on the type of training (dynamic), the mode of testing (isokinetic, isometric, or dynamic), and duration of training [Goto et al., 2004]. However, there is convincing evidence in the literature to indicate that similar benefits in terms of strength improvements can be achieved using much lower training intensities and durations of training if combined with the KAATSU training technique (Table 1).

Following 8 weeks of unilateral elbow flexion training (one arm was trained with restriction and the other without restriction) at 50\% 1-RM, isometric MVC increased by $8.3 \%$ with blood flow restriction, but no significant change was observed without restriction [Moore et al., 2004]. The same exercise protocol with blood flow restriction to only one limb also resulted in a $10.5 \%$ increase in isokinetic strength versus $9.6 \%$ without KAATSU and a $22 \%$ increase in isotonic strength in elbow flexors with KAATSU compared to a $23 \%$ increase without KAATSU, with the increases in both conditions being statistically similar [Burgomaster et al., 2003]. The authors could not offer any physiological reasons why both limbs would respond in a similar fashion, contrary to all other published KAATSU protocols [Burgomaster et al., 2003]. We hypothesize that the adaptation to training may be affected by the mode of testing, because the mechanisms responsible for the changes in strength may be similar for isokinetic and isotonic strength, but different for isometric strength.

A 4-week training program of repeated isometric knee extensions at $40 \%$ of MVC resulted in significant increases in MVC values by $9 \%$ after the first 2 -weeks and of $26 \%$ after the entire 4 -week training period [Shinohara et al., 1998]. When dynamic knee extension exercises at 20\% 1-RM were performed for 7 days, the authors reported a $17 \%$ and a 14\% increase in MVC and 1-RM strength, respectively [Abe et al., 2005a]. In a somewhat similar study, a low intensity resistance training protocol was used in combination with blood flow restriction for two weeks, which resulted in $16.8 \%$ and $22.6 \%$ increases in squat and leg curl 1-RM strength, respectively. However, the control group performing the same exercises without blood restriction experienced only $8.9 \%$ and $1.3 \%$ increases in squat and leg curl 1-RM strength, respectively [Abe et al., 2005b]. In another 2-week study of twice-daily training that included three sets of leg curls and squats at $20 \% 1-R M$, the l-RM squat strength increased by $14 \%$ [Yasuda et al., 2005]. Takarada et al. (2004) reported a 9.2\% increase in isokinetic strength in the knee extensors after an 8-week training program consisting of five sets of knee extension exercises ( $20 \%$ l-RM) with KAATSU, but the isokinetic strength change in knee extensors in the group performing the same exercises without
KAATSU was only $3.1 \%$. Trained elite athletes also experienced a $14.3 \%$ strength gain after completion of an 8-week KAATSU training program of the knee extensor muscles at about $50 \%$ of 1-RM [Takarada et al., 2002].

\section{Gender effects}

Although the subject population for most of the KAATSU studies were young males, postmenopausal females also increased isokinetic strength in elbow flexors by $18.4 \%$ following a 16 -week resistance training (30-50\% $1-\mathrm{RM})$ combined with vascular restriction [Takarada et al., 2000b]. Subjects in the KAATSU group exercised the contralateral arm with a high-intensity ( $80 \% 1-\mathrm{RM})$ exercise without restriction and increased isokinetic strength of the elbow flexors by $22.6 \%$, similar to the arm trained with blood flow restriction. However, when exercises were performed at the same low intensity $(30-50 \%$ 1-RM) with no blood flow restriction, there was only a $1.0 \%$ increase in strength. Gender does not appear to influence the adaptive ability of skeletal muscle in response to KAATSU training, with similar adaptations being demonstrated by both males and females.

\section{b. Neural response}

Another noninvasive technique that has been used to determine motor unit activation and post activation potentiation (PAP) is twitch interpolation [Allen et al., 1995]. This technique involves electrical stimulations applied to the muscle or nerve during and after isometric MVC (Shield and Zhou, 2004). PAP, which can improve muscular performance, is the first twitch obtained after a MVC trial [Moore et al., 2004]. Eight weeks of low intensity $(50 \%$ of 1 RM) unilateral elbow flexion training with restricted blood flow resulted in a significant increase in PAP ( $51 \%)$, but no change was observed after low intensity exercise without blood flow restriction. No significant difference in increased dynamic strength was reported between the two conditions $(22 \%$ increase with restricted blood flow and $23 \%$ increase without restriction); however, isometric strength (MVC) improved significantly more $(8.3 \%)$ for the KAATSU condition compared to the control (no change). Additionally, resting twitch torque was depressed by $21 \%$ with vascular occlusion but was not changed in the unrestricted blood flow condition which might be attributed to low frequency fatigue in response to the KAATSU training regiment [Moore et al., 2004].

\section{ACUTE RESPONSES \\ Neural response}

Surface electromyography (EMG) reflects the linear algebraic summation of muscle action potentials that 
propagate within the electrode recording areas. The time and frequency domains of the EMG signal may reflect muscle activation (combination of motor unit recruitment and firing rate) and motor unit action potential conduction velocity via the global shape of the action potentials, respectively [Basmajian and De Luca, 1985]. EMG signals were recorded from the triceps brachii and the pectoralis major during bench press exercises with or without vascular restriction [Yasuda et al., 2006] (Table 2). Normalized integrated EMG (iEMG) increased gradually during four sets of the dynamic exercise at 30\% 1-RM; however, the magnitude of the EMG response for both the triceps brachii and the pectoralis major were significantly higher when KAATSU was applied.

Normalized iEMG determined that the exercise intensity for the first set was the same for both the control and KAATSU session, but the intensity of exercise was higher in the KAATSU session during the forth set [Yasuda et al., 2006]. Takarada et al. (2000b) also reported that the relative iEMG was $40 \%$ lower during low-intensity exercise $(\sim 50 \% 1$ RM) without restriction compared to iEMG values during high-intensity exercise ( $80 \%$ 1-RM) with no restriction indicating that there is a positive relationship between the level of the force exerted and iEMG activity. Restriction pressure was increased gradually during low-intensity exercise resulting in gradual increases in iEMG. This may be due to increasing lactic acid production inhibiting contraction of muscle fibers leading to the recruitment of additional motor units. However,

Table 2.

The Acute Effects of Vascular Restriction on Skeletal Muscle Physiology

\begin{tabular}{|c|c|c|c|c|c|c|c|c|c|c|}
\hline Author & Group & $\begin{array}{l}\text { Duration } \\
\text { of Study } \\
\text { (Week) }\end{array}$ & $\mathbf{N}$ & Gender & Set $x$ Rep & Intensity & $\begin{array}{l}\text { Change in } \\
\text { CSA } \\
\text { Increase }(\uparrow) \\
\text { Decrease }(\downarrow)\end{array}$ & $\begin{array}{l}\text { Change in } \\
\text { Strength } \\
\text { Increase }(\uparrow) \\
\text { Decrease }(\downarrow)\end{array}$ & $\begin{array}{l}\text { Change in EMG, } \\
\text { MMG, motor unit } \\
\text { activation, PAP } \\
\text { Increase }(\uparrow) \\
\text { Decrease }(\downarrow)\end{array}$ & Comments \\
\hline $\begin{array}{l}\text { Karabulut } \\
\text { et al. } \\
\text { (2006) }\end{array}$ & $\mathrm{E}$ & $\begin{array}{l}\text { one session } \\
\text { one session }\end{array}$ & 12 & M & $\begin{array}{l}5 \times 20 \\
\text { isometric } \\
\text { knee } \\
\text { extension } \\
\text { with } \\
\text { Kaatsu } \\
\text { ( } 2 \mathrm{~s} \text { on } 1 \mathrm{~s} \\
\text { off) } \\
5 \times 20 \\
\text { isometric } \\
\text { knee } \\
\text { extension } \\
\text { without } \\
\text { Kaatsu } \\
\text { (2s on 1s } \\
\text { off) }\end{array}$ & $20 \% 1-\mathrm{RM}$ & NA & $\begin{array}{l}\text { No sig. change } \\
\text { in MVC, } \\
\text { No sig. change } \\
\text { in MVC }\end{array}$ & $\begin{array}{l}\text { No sig. change in } \\
\text { EMG amplitude } \\
\text { (amp.), EMG mean } \\
\text { power frequency } \\
\text { (MPF), MMG amp, } \\
\text { MMG MPF } \\
\text { There were sig. } \\
\text { difference between } \\
\text { repetitions \& MMG } \\
\text { amp. increased from } \\
\text { set-1 to set-2 }\end{array}$ & $\begin{array}{l}7 \%(\downarrow) \text { in } \\
\text { isometric } \\
\text { MVC in } \\
\text { Kaatsu session } \\
\text { (not sig.) vs. } \\
2 \%(\downarrow) \text { in } \\
\text { isometric } \\
\text { MVC in no- } \\
\text { Kaatsu session } \\
\text { (not sig.) } \\
\text { Same subject } \\
\text { performed } \\
\text { same exercises } \\
\text { without } \\
\text { Kaatsu } \\
\text { The cuff } \\
\text { pressure= } \\
\text { (Arm } \\
\text { SBPx1.2)x } 1.2\end{array}$ \\
\hline $\begin{array}{l}\text { Takarada } \\
\text { et al. } \\
\text { (2000b) }\end{array}$ & $\mathrm{E}$ & $\begin{array}{l}\text { one session } \\
\text { one session } \\
\text { one session }\end{array}$ & 5 & $\mathrm{M}$ & $\begin{array}{l}\text { Subjects } \\
\text { performed } \\
5 \text { sets of } \\
\text { single-arm } \\
\text { dumbbell } \\
\text { curl, each } \\
\text { set until } \\
\text { failure }\end{array}$ & $\begin{array}{l}-80 \% 1- \\
\text { RM } \\
\text { (without } \\
\text { restriction) } \\
\\
\\
\sim 50 \% 1 \text { - } \\
\text { RM } \\
\text { (without } \\
\text { restriction) }\end{array}$ & NA & NA & $\begin{array}{l}\text { Sig. change } \\
40 \% \text { higher iEMG } \\
\text { than that of control } \\
\text { group with no- } \\
\text { restriction } \\
\text { NA }\end{array}$ & $\begin{array}{l}\text { Mean cuff } \\
\text { pressure: } 0-100 \\
\text { mmHg } \\
\text { 1-minute rest } \\
\text { between sets. } \\
\text { Repeated the } \\
\text { lifting until } \\
\text { failure. } \\
\text { No sig. change } \\
\text { between iEMG } \\
\text { values @ 100 } \\
\text { mmHg and } \\
\text { during high } \\
\text { intensity without } \\
\text { restriction }\end{array}$ \\
\hline $\begin{array}{l}\text { Yasuda et } \\
\text { al. (2006) }\end{array}$ & $\mathrm{E}$ & $\begin{array}{l}\text { One } \\
\text { session }\end{array}$ & 12 & $\begin{array}{l}\text { M \& } \\
F\end{array}$ & $\begin{array}{l}30 \text { reps }+ \\
3 \times 15 \\
\text { (bench } \\
\text { press) } \\
\\
30 \text { reps + } \\
3 \times 15 \\
\text { (bench } \\
\text { press) }\end{array}$ & $30 \%$ 1-RM & NA & NA & $\begin{array}{l}\text { During first } 30 \text { reps= } \\
\text { iEMG } \sim 40 \% \text { of } 1- \\
\text { RM } \\
3^{\text {rd }} \text { set= iEMG } \sim 60- \\
70 \% 1-\text { RM } \\
\text { During first } 30 \text { reps= } \\
\text { iEMG } \sim 40 \% \text { of } 1- \\
\text { RM } \\
3^{\text {rd }} \text { set= iEMG } \sim 50 \% \\
1-\text { RM }\end{array}$ & $\begin{array}{l}\text { The cuff } \\
\text { pressure= } \\
\text { Equaled to } \\
\text { individual's } \\
\text { resting } \\
\text { systolic blood } \\
\text { pressure } \\
30 \mathrm{sec} \text { rest } \\
\text { between sets }\end{array}$ \\
\hline
\end{tabular}

Table was organized according to alphabetical order of names. N= Number of subjects; Freq= Frequency; Rep= Repetitions; $\mathrm{E}=\mathrm{Exercise}$ group; $\mathrm{C}=\mathrm{Con}$ trol group; $\mathrm{M}=$ Male; $\mathrm{F}=$ Female; $\mathrm{NA}=$ Not applicable. 
there was not a significant difference in iEMG values during low-intensity exercise with blood flow restriction at $100 \mathrm{mmHg}$ and high-intensity exercise without restriction. A possible explanation for this finding might be that the magnitude of blood pooling affected the surface EMG electrode recordings.

The mechanomyogram (MMG) records and quantifies the low-frequency lateral oscillations of active skeletal muscle fibers [Barry and Cole, 1990; Orizio, 1993]. During voluntary muscle actions, the MMG signal represents a summation of the mechanical activity from individual motor units. The time and frequency domains of the MMG signal have been suggested to reflect motor unit recruitment and firing rate, respectively [Beck et al., 2007; Orizio, 1993]. MMG signals were recorded from the vastus lateralis muscle during repetitive isometric contractions at 20\% MVC [Karabulut et al., 2006] (Table 2). There were no significant interactions and no significant main effects for pre- versus postexercise or with-versus without blood flow restriction for either MMG amplitude or MMG mean power frequency (MPF). MMG amplitude increased from set 1 to 2 , but there was no difference between sets $2,3,4$, and 5 for both the restricted and nonrestricted sessions; however, the authors suggested that it was possible that the isometric exercise task was at too low of an intensity and did not result in any substantial changes in motor unit firing rates [Karabulut et al., 2006]. Table 2 summarizes the data for the acute responses of skeletal muscle to a single bout of KAATSU training. Since no previous studies have examined the MMG responses to KAATSUrelated interventions, it was not possible to compare these findings to other studies.

\section{CONCLUSION}

There seems to be some agreement that blood flow restriction during low intensity exercise can potentiate physiological improvements in skeletal muscle, apparently independent of the commonly accepted training principles associated with overload and progression. These changes in skeletal muscle size and strength may possibly be through neuromuscular adaptations such as improved muscle and/or nerve coordination and/or muscle hypertrophy and appear to be independent of gender, training status, and age. It should also be noted that there are probably numerous factors involved in muscle hypertrophy and strength changes such as metabolite accumulation (lactic acid, ADP, etc.), induced hypoxia, reperfusion of the muscle, and localized or systemic endocrine responses (Growth Hormone, Insulin-like Growth Factor-1, Testosterone, etc.).

One possible explanation for the relatively faster hypertrophic response (even after one week of KAATSU training) compared to traditional resistance training programs may be the recruitment of more fast-twitch fibers and their higher threshold motor units. It is difficult to determine which factors are more important since there are close relationships between these various factors.

Since low-intensity exercises combined with vascular restriction requires less mechanical stress ( $20 \%$ versus $80 \% 1-R M)$, it may be an effective alternative method to increase strength and muscle size and used for strength training in the elderly or for people with orthopedic injuries. In addition, KAATSU training programs may also provide an opportunity to use different exercise modes such as walking for the purpose of muscle hypertrophy and strength gains. In summary, additional studies are required to clarify the physiology of the underlying factors associated with KAATSU training; however, it seems to be a potentially useful training method for improving the quality of life in the elderly, enhancing performance in athletes, and shortening rehabilitation time in patients.

\section{SUGGESTIONS FOR FUTURE RESEARCH}

One physiological system that needs further research is the area of bone physiology and the use of KAATSU training. Various situations like rehabilitation from injury (limb immobilizations, casting, etc), bed rest (hip or knee replacement, etc), and the loss of gravity (space flight) each have specific needs for being able to prevent bone and muscle loss which might be best accomplished with the aid of blood flow restriction and low intensity exercise.

Additionally, the longest published KAATSU training study lasted 16 weeks; therefore, more research is needed to understand the long-term effects of KAATSU training, especially since bone is typically much slower in responding to a training stimulus. Finally, other interesting areas of research could include the examination of the time course of the adaptive changes following the termination of KAATSU training or the implications of switching from KAATSU training to a traditional resistance training program (or vise versa) compared to similar length, single mode training programs (KAATSU or traditional resistance training).

\section{References}

Abe T, Yasuda T, Midorikawa T, Sato Y, Kearns CF, Inoue K, Koizumi K, Ishii N (2005b) Skeletal muscle size and circulating IGF-1 are increased after two weeks of twice daily "KAATSU" resistance training. Int. J. KAATSU Training Res. 1:6-12.

Abe T, Beekley MD, Hinata S, Koizumi K, Sato Y (2005a) Day-to-day change in muscle strength and MRI-measured skeletal muscle size during 7 days KAATSU resistance training: A case study. Int. J. KAATSU Training Res. 1:71-76.

Abe T, Kearns CF, Sato $Y(2006)$ Muscle size and strength are increased following walk training with restricted venous blood flow from 
the leg muscle, Kaatsu-walk training. J Appl Physiol 100:1460-6. Allen GM, Gandevia SC, McKenzie DK (1995) Reliability of measurements of muscle strength and voluntary activation using twitch interpolation. Muscle Nerve 18:593-600.

Baechle TR, Earle RW (2000) Essentials of Strength Training and Conditioning. 2.nd ed. Human Kinetics, Champaign, IL, pp. 412-415.

Barry DT, Cole NM (1990) Muscle sounds are emitted at the resonant frequencies of skeletal muscle. IEEE Trans Biomed Eng 37:525-31.

Basmajian JV, De Luca CJ (1985) Muscles alive: their functions revealed by electromyography. 5th ed. Williams \& Wilkins, Baltimore, pp. 201-222.

Beck TW, Housh TJ, Johnson GO, Cramer JT, Weir JP, Coburn JW, Malek MH (2007) Does the frequency content of the surface mechanomyographic signal reflect motor unit firing rates? A brief review. J Electromyogr Kinesiol 17:1-13.

Beekley MD, Sato Y, Abe T (2005) KAATSU-walk training increases serum bone-specific alkaline phosphatase in young men. Int. J. KAATSU Training Res. 2:77-81.

Burgomaster KA, Moore DR, Schofield LM, Phillips SM, Sale DG, Gibala MJ (2003) Resistance training with vascular occlusion: metabolic adaptations in human muscle. Med Sci Sports Exerc 35:1203-8.

Goto K, Ishii N, Kizuka T, Takamatsu K (2005) The impact of metabolic stress on hormonal responses and muscular adaptations. Med Sci Sports Exerc 37:955-63.

Goto K, Nagasawa M, Yanagisawa O, Kizuka T, Ishii N, Takamatsu K (2004) Muscular adaptations to combinations of high- and low-intensity resistance exercises. J Strength Cond Res 18:730-7.

Grimby G, Danneskiold-Samsoe B, Hvid K, Saltin B (1982) Morphology and enzymatic capacity in arm and leg muscles in 78-81 year old men and women. Acta Physiol Scand 115:125-34.

Ishii N, Madarame H, Odagiri K, Naganuma M, Shinoda K (2005) Circuit training without external load induces hypertrophy in lower-limb muscles when combined with moderate venous occlusion. Int. J. KAATSU Training Res. 1:24-28.

Karabulut M, Cramer JT, Ryan ED, Anderson RL, Hull HR, Abe T, Sato $Y$, Bemben MG (2006) Effects of KAATSU on muscular function during isometric exercise. Int. J. KAATSU Training Res. 2:19-28.

Lexell J, Henriksson-Larsen K, Winblad B, Sjostrom M (1983) Distribution of different fiber types in human skeletal muscles: effects of aging studied in whole muscle cross sections. Muscle Nerve 6:588-95.

McCall GE, Byrnes WC, Fleck SJ, Dickinson A, Kraemer WJ (1999) Acute and chronic hormonal responses to resistance training designed to promote muscle hypertrophy. Can J Appl Physiol 24:96-107.

Moore DR, Burgomaster KA, Schofield LM, Gibala MJ, Sale DG, Phillips SM (2004) Neuromuscular adaptations in human muscle following low intensity resistance training with vascular occlusion. Eur J Appl Physiol 92:399-406.

Orizio C (1993) Muscle sound: bases for the introduction of a mechanomyographic signal in muscle studies. Crit Rev Biomed Eng 21:201-43.

Pollock ML, Carroll JF, Graves JE, Leggett SH, Braith RW, Limacher M, Hagberg JM (1991) Injuries and adherence to walk/jog and resistance training programs in the elderly. Med Sci Sports Exerc 23:1 194-200.

Russell B, Motlagh D, Ashley WW (2000) Form follows function: how muscle shape is regulated by work. J Appl Physiol 88:1 127-32.

Sata S (2005) Kaatsu training for patella tendinitis patient. Int. J. KAATSU Training Res. 1:29-32.

Sato $Y$ (2005) The history and future of KAATSU Training. Int. J. KAATSU Training Res. 1:1-5.

Shield A, Zhou S (2004) Assessing voluntary muscle activation with the twitch interpolation technique. Sports Med 34:253-67.

Shinohara M, Kouzaki M, Yoshihisa T, Fukunaga T (1998) Efficacy of tourniquet ischemia for strength training with low resistance. Eur J Appl Physiol Occup Physiol 77:189-91.

Takarada Y, Sato Y, Ishii N (2002) Effects of resistance exercise combined with vascular occlusion on muscle function in athletes. Eur $\mathrm{J}$ Appl Physiol 86:308-14.

Takarada Y, Takazawa H, Ishii N (2000a) Applications of vascular occlusion diminish disuse atrophy of knee extensor muscles. Med Sci Sports Exerc 32:2035-9.

Takarada Y, Takazawa H, Sato Y, Takebayashi S, Tanaka Y, Ishii N (2000b) Effects of resistance exercise combined with moderate vascular occlusion on muscular function in humans. J Appl Physiol 88:2097-106.

Takarada Y, Tsuruta T, Ishii N (2004) Cooperative effects of exercise and occlusive stimuli on muscular function in low-intensity resistance exercise with moderate vascular occlusion. Jpn J Physiol 54:585-92.

Yasuda T, Abe T, Sato Y, Midorikawa T, Kearns CF, Inoue K, Ryushi T, Ishii N (2005) Muscle fiber cross-sectional area is increased after two weeks of twice daily KAATSU-resistance training. Int. J. KAATSU Training Res. 1:65-70.

Yasuda T, Fujita T, Miyagi Y, Kubota Y, Sato Y, Nakajima T, Bemben MG, Abe T (2006) Electromyographic responses of arm and chest muscle during bench press exercise with and without KAATSU. Int. J.KAATSU Training Res. 2:15-18.

Yoshida T, Watari H (1997) Effect of circulatory occlusion on human muscle metabolism during exercise and recovery. Eur J Appl Physiol Occup Physiol 75:200-5.

\section{Authors' affiliations}

M. Karabulut, M. Bemben, Neuromuscular Laboratory, Department of Health and Exercise Science, University of Oklahoma Norman, OK, USA

T. Abe, Department of Human and Engineered Environment, Gaduate School of Frontier Sciences, University of Tokyo, Kashiwa, Chiba, Japan Y. Sato, Department of Ischemic Circulatory Physiology, University of Tokyo, Hongo, Tokyo, Japan 